\title{
Zoonotic parasites carried by invasive alien species in China
}

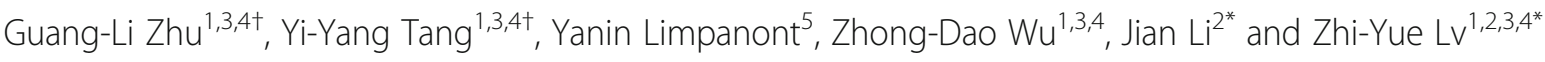

\begin{abstract}
Background: The invasive alien species may lead to great environmental and economic crisis due to its strong capability of occupying the biological niche of native species and altering the ecosystem of the invaded area. However, its potential to serve as the vectors of some specific zoonotic pathogens, especially parasites, has been neglected. Thus, the damage that it may cause has been hugely underestimated in this aspect, which is actually an important public health problem. This paper aims to discuss the current status of zoonotic parasites carried by invasive alien species in China.

Main body: This review summarizes the reported zoonotic parasites carried by invasive alien species in China based on the Database of Invasive Alien Species in China. We summarize their prevalence, threat to human health, related reported cases, and the roles of invasive alien species in the life cycle of these parasites, and the invasion history of some invasive alien species. Furthermore, we sum up the current state of prevention and control of invasive alien species in China, and discuss about the urgency and several feasible strategies for the prevention and control of these zoonoses under the background of booming international communications and inevitable globalization.

Conclusions: Information of the zoonotic parasites carried by invasive alien species neither in China or worldwide, especially related case reports, is limited due to a long-time neglection and lack of monitoring. The underestimation of their damage requires more attention to the monitoring and control and compulsory measures should be taken to control the invasive alien species carrying zoonotic parasites.
\end{abstract}

Keywords: Invasive alien species, Zoonotic parasite, China

\section{Multilingual abstracts}

Please see Additional file 1 for translations of the abstract into the five official working languages of the United Nations.

\section{Background}

Invasive alien species (IAS) are non-native species introduced deliberately or unintentionally outside their natural habitats where they become established, proliferate and spread in ways that cause damage to a wide range of interests [1].

\footnotetext{
* Correspondence: lijian5@mail.sysu.edu.cn; Ivzhiyue@mail.sysu.edu.cn

${ }^{\dagger}$ Guang-Li Zhu and Yi-Yang Tang contributed equally to this work.

${ }^{2}$ Fifth Affiliated Hospital, Sun Yat-sen University, Zhuhai 519000, Guangdong, China

'Zhongshan School of Medicine, Sun Yat-sen University, Guangzhou 510080,

China

Full list of author information is available at the end of the article
}

The screening and monitoring of IAS is of urgent requirement due to its potential capability to damage ecology, economy and most alarmingly, public health. Probably because of the absence of its predators and the great adaptability to different environments, IAS invade and occupy the ecological niche of the native and destructs local biodiversity. Giving its catastrophic nature, IAS have already been regarded as the second greatest factor of species extinction and endangerment [2]. Additionally, the economic loss associated with IAS sums up to about 120 billion dollar/year in the United States of America [3]. The economic loss caused by IAS was estimated nearly 19.8 billion CNY in China [4]. However, the risks from IAS to public health have been neglected. The IAS themselves can impair human health directly. For example, a sting of red imported fire ant (Solenopsis invicta) can cause severe anaphylactic reaction to human beings [5]. In addition, as either the

(c) The Author(s). 2019 Open Access This article is distributed under the terms of the Creative Commons Attribution 4.0 International License (http://creativecommons.org/licenses/by/4.0/), which permits unrestricted use, distribution, and 
vector or reservoir host of parasites, IAS will carry not only the native parasites, but also the non-native ones, which may threaten the public health, and delay the diagnosis and treatment simply due to the unfamiliar of the native doctors to the pathogens.

With a vast territory of approximate 9.6 million square kilometers covering almost all ecosystems in the world, there are always suitable habitats for many non-native species in China. In addition to a long history of the introduction of non-native species, the rapid development of economy, technology and transportation system since Chinese Economic Reform has also greatly increased the risk of biological invasion by non-native species, accompanied with the increasing in population density and trading activities.

In 2017, according to the Database of Invasive Alien Species in China (www.chinaias.cn) published by Center for Management of Invasive Alien Species, Ministry of Agriculture, a total of 270 invasive alien animal species have been recorded, including one myxozoa, 14 moss animals, one annelid, one echinoderm, 17 nematodes, 20 mollusks, 153 arthropods (140 insects), six ascidians, 34 fishes, four amphibians, three reptiles, six birds, 10 mammals.

About two thirds of the invasive alien species were introduced intentionally [6]. Before the concept of biological invasion were widely accepted, the species introduction was mainly focused on socioeconomic benefit. It was not until middle of 1990s when several Chinese scientists' papers introduced the concept and impact of IAS that the government and the public began to take actions to deal with the problem of IAS. For such a long time, the impact of IAS had been neglected, especially their impact on public health [7]. As vectors of native pathogens, expanding IAS may lead to an increase of infection rate. [8]. What's worse, the novel non-native pathogens introduced by these IAS may even cause an outbreak in the native populations. More attention to these parasites should be aroused [9]. This paper aims to discuss the current knowledge of zoonotic parasites carried by invasive mollusks, arthropods and vertebrates in China, mainly focusing on the category, clinical aspects and administration and international cooperation to prevent and control the problems.

\section{Invasive alien mollusk harboring zoonotic parasites}

Most mollusks IAS capable of carrying parasites and transmitting parasitic disease are freshwater snails and human may be infected by ingesting raw or undercooked snail. The most common species include the Pomacea canaliculata, Achatina fulica Bowditch and Biomphalaria straminea (Dunker).

\section{Pomacea canaliculata}

$P$. canaliculata, which is commonly known as golden apple snail, originated from Argentina, was first introduced into Taiwan in the 1970s and mainland China in 1981 [6] as edible material [10]. With its wide tolerance toward different environments and high reproduction rate, the snail exhibits the capability to establish wild populations rapidly in new habitats [11]. And it has already spread to at least 16 PAM (province/autonomous region/municipality) in China including Taiwan, Guangdong, Guangxi, Fujian, Zhejiang, Jiangsu, Shanghai, Hubei, Jiangxi, Liaoning, Beijing, Anhui, Sichuan, Chongqing, Gansu, Tianjin [12].

Based on the biology of the snail and the meteorological database of 670 weather sites distributed all across China during 1951-1980, the researchers worked out a model to predict the potential habitat for the species. The model suggested that about $52.1 \%$ regions represented by the above weather sites (about 2563000 $\mathrm{km}^{2}$ ) were vulnerable to the colonization of the $P$. canaliculate [13]. Considering the future climate change and the inevitable trend of global warming, an area of approximately $378700 \mathrm{~km}^{2}$ is expected to be occupied by $P$. canaliculata from the 2020 s to the 2030s, in which the distribution could move further northeast, even covering the Huaihe River valley [12]. The $P$. canaliculata poses a huge threat to the agriculture industry as well. It is reported to be potential pest for 15 important economic agricultural crops in China [14]. Also, P. canaliculata is able to spread rapidly into wetland [15] and other freshwater ecosystems, resulting in severe habitat modification and a decrease of local biodiversity [16].

Apart from its direct destruction to the ecosystem, $P$. canaliculata is able to impair the human health directly as the intermediate host of several parasites such as Echinostoma revolutum, Angiostrongylus cantonensis and Gonathostoma spinigerum which respectively cause echinostomiasis, angiostrongyliasis and gnathostomiasis [17].

Angiostrongyliasis is the most common cause of eosinophilic meningitis in southeast Asia and the Pacific basin [18] and usually results from consuming the undercooked snail or other mollusk which carry the infectious larvae of A. cantonensis [19]. The first case reported came from Taiwan in 1945 [20], and was first discovered in Guangdong Province (mainland China) in 1984 [21]. From 2000 to 2006, six outbreaks has attracted the public's attention [22], among which the most serious one occurred in Beijing in 2006 involving 160 infected and 100 hospitalized [23].

Echinostomiasis is caused by orally intaking the metacercaria of the family Echinostomatide via the raw or undercooked infected snails [24]. The number of involved provinces in mainland China had reached eight by 1994, including Heilongjiang, Sichuan, Yunnan, 
Zhejiang, Fujian, Hubei, Guangdong, Anhui [25]. In some coastal provinces like Fujian and Guangdong where edible snails are easily accessible, the prevalence of the disease even reaches 5.0\% [26].

G. spinigerum is another parasite that may be carried by $P$. canaliculata [27]. Nevertheless, it is unusual to find a patient infected after consumed the snail. Almost all the cases reported in China got infected by the raw or undercooked fish and the incidence is rather low. From 1919, when index case in China came out to 2011, only 73 cases covering 16 PAM were reported, among which Zhejiang, Shanghai, Fujian, Guangdong had higher incidence [28].

\section{Achatina fulica}

Another invasive mollusk capable of transmitting parasites is the A. fulica, also known as giant Africa snail. It is firstly discovered in Xiamen, Fujian Province in the plant carried by a Singapore overseas Chinese in 1931 [29]. After settling down in Xiamen, it began to scatter in southern part of mainland China including Guangdong, Hainan, Guangxi. It invaded Hong Kong, Macau in 1932 and Taiwan in 1933 [30]. The snail in Yunnan was introduced in 1979 from Vietnam [31].

Its various trophic preference and high reproductive ability make it pest for many agricultural crops and ornamental plants. The rapid establishment and expansion can jeopardize the biodiversity and impair the local plants and animals [32]. Besides, it is capable to carry many pathogens which harm human health directly such as A. cantonensis [33]. Due to its biological characteristics, A. fulica is even more vulnerable to the infection of A. cantonensis than P. canaliculata. A survey conducted in Jiangmen, Guangdong Province indicate that the infection rate of A. fulica and P. canaliculata by A. cantonensis reached 41.9 and $1.8 \%$, and the degree of infection was 1-928 per snail and 1-29 per snail respectively [34]. But the threaten caused by A. fulica are not as severe as the $P$. canaliculata because of its terricolous feature [22]. A. fulica can be infected by the $A$. costaricensis larvae under laboratory condition, so the snail can be the intermediate host of $A$. costaricensis as well [35]. However, no relevant case has been reported in China yet.

\section{Biomphalaria straminea}

B. straminea attracts attention as the intermediate host of Schistosoma mansoni, which may lead to schistosomiasis [36]. The B. straminea, originated from South America, was first discovered in Hong Kong in 1974 and was thought to be introduced abroad. Later in 1981, it appeared in a pond in the Luohu District of Shenzhen City, which was the first report in mainland China [37]. By 2013, the snail had spread in large range of Shenzhen and overspread to the surrounding regions such as Dongguan and Huizhou in Guangdong Province [38]. While no infection of B. straminea by Sc. mansoni in China has been detected, Sc. mansoni infection in the returnees of China from Africa is increasing in recent years [39]. Because Shenzhen and surrounding regions are key area of labor exporting with large population mobility and numerous international communications, some experts presumed that China is now equipped with the objective condition for the prevalence of Sc. mansoni [40]. B. straminea was also found capable of carrying the larvae of $A$. cantonensis in Brazil, which may cause angiostrongyliasis but there is no such a case reported in China yet [41].

The information concerning the invasive alien mollusks and the parasites carried by them worldwide is listed in Table 1.

\section{Invasive alien arthropods harboring zoonotic parasites Invasive alien crustaceans harboring zoonotic parasites}

Procambarus clarkii, also commonly acknowledged as the red swamp crayfish or red swamp crawfish, is the native species of North America [42]. It was introduced to Japan in 1918, and then brought into Nanjing, China in the 1930s during the Second World War from Japan [43]. Nowadays, it expanded all over China as an important food resource [44] and the sales are becoming increasingly larger [45], but it is not completely safe. In 1952, Paragonimus westermani was first discovered in $P$. clarkii in Japan [46]. People may get infected through the intake of the undercooked crayfish [47]. The paragonimiasis is a zoonotic disease prevailing in 25 PAM at varied extent and has higher incidence in southwest China including Sichuan, Chongqing and Yunnan [48]. More than 100 counties in Sichuan Province had reported cases through past 50 years and the incidence shows an upward trend because of the changing in the lifestyle and diet [49]. However, there has been no definite report regarding to $P$. clarkii as the cause of the paragonimiasis in China so far. Patients commonly got infected by consuming the undercooked Potamon spp., or some freshwater snails or through direct contact with the contaminated water. This could be explained by the fact that most edible $P$. clarkii in China comes from the aquafarm where the safety is guaranteed.

\section{Invasive alien insects harboring zoonotic parasites}

Most invasive alien insects in China have a closer relationship with plants instead of animals except Blattella germanica, Periplaneta Americana, Periplaneta australasiae, S. invicta and so on.

Tribolium castaneum The Tribolium castaneum (Herbst), also known as red floor betel, is recognized as 
Table 1 Zoonotic parasites carried by invasive alien mollusks

\begin{tabular}{|c|c|c|c|}
\hline Species & Common name & Parasites & Reference \\
\hline \multirow[t]{3}{*}{ Mytilus galloprovincialis Lamarck } & \multirow[t]{3}{*}{ Mediterranean mussel } & Cryptosporidium parvum & [111] \\
\hline & & Giardia duodenalis & [112] \\
\hline & & Toxoplasma gondii & [113] \\
\hline \multirow[t]{3}{*}{ Dreissena polymorpha } & \multirow[t]{3}{*}{ Zebra mussel } & Acanthamoeba spp. & [114] \\
\hline & & Cryptosporidium spp. & {$[115]$} \\
\hline & & G. duodenalis & [116] \\
\hline \multirow[t]{3}{*}{ Pomacea canaliculata } & \multirow[t]{3}{*}{ Golden apple snail } & A. cantonensis & [19] \\
\hline & & Echinostoma revolutum & [24] \\
\hline & & Gonathostoma spinigerum & [27] \\
\hline \multirow[t]{2}{*}{ Achatina fulica Bowditch } & \multirow[t]{2}{*}{ Giant African snail } & Angiostrongylus costaricensis & {$[35]$} \\
\hline & & A. cantonensis & [33] \\
\hline \multirow[t]{2}{*}{ Biomphalaria straminea Dunker } & & Schistosoma mansoni & {$[36]$} \\
\hline & & A. cantonensis & [117] \\
\hline
\end{tabular}

the pest of stored grain. The species distributes worldwide in 6 continents except the Antarctica according to the Bureau of Entomology and Plant Quarantine, United States Department of Agriculture [50]. It was reported that the betel could only be found in 4 provinces in China by the 1960s. The species made its way through the transportation and trading of grain food. In consideration of the tradition of food allocation and transportation around China, researchers assumed the $T$. castaneum as one of the IAS [51]. Nowadays, this specie has invaded 23 PAM of China, while no evidence found in Shanghai, Shanxi, Shaanxi, Qinghai, Gansu, Xinjiang, Taiwan, Guizhou and Tibet [52].

T. castaneum is experimentally proved as the potential intermediate host for Pseudanoplocephala crawfordi, which may cause psudanoplocephalosis [53]. P. crawfordi inhabits in the small intestines of many mammals including the swine, mouse and human. The patients usually take on some abdominal symptoms [54]. The prevalence of the parasites in the swine of China can reach $15.2-91.6 \%$ which makes it a big threat to the livestock industry [55]. Twenty-one cases [56] related to this parasite had been reported in Henan [56], Liaoning [53] and Shaanxi [57] until 2016. Patients can be infected by undertaking insanitary food contaminated by the T. castaneum or eating the $T$. castaneum carrying the cysticercoids directly.

Cockroaches Cockroach is one of the most common synanthropic insects in the world, especially in the areas with bad sanitary condition. In China, before 1980s, the dominant species of city cockroaches are $P$. americana, while the distribution of $B$. germanica is limited to several cities. Later, the invasive $B$. germanica replaced $P$. americana to be the dominant species in city and spread nationwide rapidly [58].

Because cockroaches usually feed on human feces, they may transmit various zoonotic parasites mechanically. An investigation in Taiwan revealed a high infection rate, $25.0 \%$ in P. americana and $10.0 \%$ in B. germanica, by Entamoeba histolytica or Entamoeba dispar respectively [59]. Besides, cockroaches can induce allergic reaction in some people directly [60].

More zoonotic parasites carried by the invasive alien insects documented worldwide are listed in Table 2.

\section{Zoonotic parasites carried by invasive alien vertebrates Zoonotic parasites carried by invasive alien fishes}

Unlike other IAS, most invasive alien fishes were initially introduced intentionally. Some of them escaped into natural water, spread rapidly and became the dominant species in local waters. More than 65 species of fishes have been introduced into China [61]. Most of them were introduced for aquaculture to increase the food supply. Since 1957, when Oreochromis mossambicus was introduced into China from Vietnam firstly, more species of tilapias had been introduced, including O. niloticus, Tilapia zillii. Now $O$. mossambicus has widely distributed in waters of South China and established wild populations [62]. Some species were introduced as ornamental species, like Hypostomus plecostomus. Some are introduced for biological control. The best-known example is the mosquitofish, Gambusia affinis, which was thought to be effective in controlling mosquitoes. However, it was proven that its effect in controlling mosquitoes did not differ from local species significantly. On the contrary, it invaded local waters by feeding on fry. Initially introduced into China from Philippine as early as 1927, mosquitofish have replaced Oryzias latipes and $O$. 
Table 2 Zoonotic parasites carried by invasive alien insects

\begin{tabular}{|c|c|c|c|}
\hline Species & Common name & Parasites & Reference \\
\hline Blatella germanica & German cockroach & $\begin{array}{l}\text { Ascariasis lumbricoides, Enterobius vermicularis, Entamoeba histolytica, E. dispar, } \\
\text { G. lamblia, hookworm, Hymenolepis nana, Strongyloides stercoralis, Sarcocystis } \\
\text { muris, Trichuris trichiura, Taenia spp., T. gondii }\end{array}$ & [118] \\
\hline \multirow[t]{4}{*}{ Periplaneta americana } & \multirow[t]{4}{*}{ American cockroach } & Moniliformis moniliformis, Diplogaster sp. & [119] \\
\hline & & $\begin{array}{l}\text { A. lumbricoides, Balantidium coli, Entamoeba coli, E. histolytica, E. vermicularis, } \\
\text { hookworm, T. trichiura }\end{array}$ & [120] \\
\hline & & S. muris, T. gondii & [121] \\
\hline & & Schistosoma haematobium, Sc. mansoni & [122] \\
\hline \multirow[t]{3}{*}{ Tribolium castaneum Herbst } & \multirow[t]{3}{*}{ Red flour beetle } & Hymenolepis diminuta & [123] \\
\hline & & Pseudanoplocephala crawfordi & [53] \\
\hline & & Steinernema feltiae & {$[124,125]$} \\
\hline Cydia pomonella & Codling moth & S. feltiae & {$[126]$} \\
\hline
\end{tabular}

Curvinotus to be local dominant species in waters of southern China [63].

Fishes are important source of zoonotic parasites. Almost all fish-borne parasitic zoonoses have been acquired by consuming raw or undercooked fish product like sushi, sashimi and so on. As is estimated by the World Health Organization (WHO), more than half billion people are exposed to the risk of these diseases [64]. The rapidly proliferating IAS may serve as a dramatically expanding source of zoonotic infection or in another way assist the transmission of these zoonotic parasites to other fishes.

\section{Fish-borne zoonotic trematodes}

Fish-borne zoonotic trematodes mainly consist of four families, including Opisthorchiidae, Heterophyidae, Nanophyetidae, and Echinostomatidae [65]. For these trematodes, fishes mainly serve as the second intermediate host [66]. Fish-borne zoonotic heterophyids mainly include Heterophyes ( $H$. heterophyes, $H$. dispar), Haplorchis ( $H$. taichui, $H$. pumilio, $H$. yokogawai, and $H$. vanissimus), Metagonimus (M. minutus, $M$. yokogawai and M. takahashii), Centrocestus (C. formosanus), Procerovum ( $P$. varium) [67]. Nine heterophyid trematodes have been reported in China, mainly in Southern China, where the patient infected with heterophyid was usually coinfected with Clonorchis sinensis due to the habit of eating raw fish [68]. Information of heterophyids infection in invasive alien fishes in China was displayed in Table 3. These zoonotic parasites were endemic in these regions correspondingly. In Longhai City and Nanjing County of Fujian Province, the infection rate of the local population is $0.3 \%(13 / 3867)$ [69]. A survey in Guangxi, where people has a habit of consuming raw fish, revealed that the infection rate of $H$. taichui reached about $24.3 \%$ there. Surprisingly, in one investigating site, $H$. taichui infection accounts for $90.5 \%$ of people with trematode infection. The most commonly consumed raw fish were C. carpio and C. auratus [70]. Besides, although experimental human infection of $C$. formosanus has been reported, natural human infection has never been recorded [71].

Among family Opisthorchiidae, three liver flukes, $C$. sinensis, Opisthorchis felineus, and O. viverrini are the most problematic zoonotic parasites [72]. For the Chinese liver fluke C. sinensis, a survey in 27 endemic PAM in China, revealed a high prevalence of about $2.4 \%$, about 12.5 million people [73]. The selectivity on second intermediate host of $C$. sinensis is low. Sixty eight species of freshwaters as latent second intermediated host of $C$. sinensis have been reported in China, including C. auratus, $C$ carpio, O. mossambica and so on $[74,75]$.

Fish-borne zoonotic cestodes Fish-borne zoonotic cestodes are mainly composed of Diphyllobothrium (D. latum and D. dendriticum) [76]. A total of 16 cases of $D$. latum infection through consuming raw fish have been reported in China, but no detailed information about the species of fish was documented [77]. D. latum infection has been recorded in Oncorhynchus mykiss, Salvelinus forntinalis, Stizostedion vitreum, Perca flavescens worldwide as listed in Table 3.

Fish-borne zoonotic nematodes Fish-borne zoonotic nematodes consist of parasites of family Gnathostomatidae (Gnathostoma spp.), family Anisakidae (Anisakis), family Capillariidae (Capillaria philippinensis), family Dioctophymatidae (Eustrongylides spp.). Among them, the most common species infecting humans are Gnathostoma spp., Anisakis spp. and Pseudoterranova spp. [78]. More than 50 cases of gnathostomiasis have been reported in 16 PAM of China. Most common infection way of Gnathostoma spp. is also consumption of raw freshwater fishes, including C. carpio, and C. auratus [79]. 
Table $\mathbf{3}$ Infection rate of heterophyids in invasive alien species in different cities in China

\begin{tabular}{|c|c|c|c|c|}
\hline Parasites & $\begin{array}{l}\text { Species of local invasive alien species } \\
\text { host }\end{array}$ & Location & Infection rate & Reference \\
\hline Haplorchis pumilio & Cyprinus carpio, Carassius auratus & Longhai City and Nanjing County of Fujian Province & $36.3 \%$ & [69] \\
\hline \multirow[t]{5}{*}{ H. taichui } & C. auratus & \multirow{9}{*}{$\begin{array}{l}\text { Yangshuo County, Nanning City, Mashan County, Fusui } \\
\text { County and Binyang County in Guangxi }\end{array}$} & $61.9 \%$ & \multirow[t]{9}{*}{ [68] } \\
\hline & C. carpio & & $42.9 \%$ & \\
\hline & Tilapia nilotica & & 0 & \\
\hline & Cirrhinus molitorella & & 0 & \\
\hline & Gambusia affinis & & - & \\
\hline \multirow[t]{4}{*}{ H. pumilio } & C. auratus & & $81.0 \%$ & \\
\hline & C. carpio & & $28.6 \%$ & \\
\hline & T. nilotica & & 0 & \\
\hline & C. molitorella & & 0 & \\
\hline Centrocestus formosanus & G. affinis, C. carpio, C. auratus & Guangdong, Fujian, Guangxi, and Taiwan & - & [127] \\
\hline
\end{tabular}

Among these fish-borne zoonotic parasitic infection cases, most of them were wild-caught fishes, while only a few were farm-raised fishes, which have been neglected for a long time. In a research conducted in Guangdong Province, where almost half of the tilapia in China is produced, zoonotic parasites of family Heterophyidae and Echinostomatidae were detected in the cultured tilapias [80].

The zoonotic parasites carried by more invasive alien fishes of China have been listed in Table 4, which is documented worldwide. Although associated information in China is limited, this table provides an insight into the potential risks of consuming these fishes in China, especially under the circumstance that infection rate in some populations, in fact is high but ignored as illustrated above, which may be attributed to the fact that most infections only cause light symptoms like diarrhea or other gastrointestinal disorders. Since most invasive alien fishes were introduced for aquaculture, more attentions should be paid to zoonotic parasites carried by these fishes.

\section{Zoonotic parasites carried by invasive alien amphibians} Invasive alien amphibians consist of Rana catesbeiana, $R$. heckscheri, $R$. grylio, $R$. tigrine, Trachemys scripta elegans and Mauremys mutica.

R. catesbeiana, bullfrog, was first introduced into China in 1959. Along with the expansion of the farming of bullfrog, some escaped into wild environments and established wild populations, but most wild populations are still small, which makes it hard to capture bullfrog in wild.

Frogs are the second intermediate host of Spirometra mansoni. A reported infection rate of Sp. masoni in bullfrog in Japan and USA were 43.0 and $1.7 \%$ respectively $[81,82]$. However, in the investigation in Zhejiang
Province and Guangzhou City, Guangdong Province, although infection rate is high in the wild frogs, like $R$. tigrina rugulosa and $R$. limnocharis, no Sp. mansoni infection was found in the farm-raised bullfrogs [83-85]. It may be associated with the absence of first intermediate host, cyclops or definitive host cat or dogs in the farming process. But high infection rate in wild frogs still alarms us that the wild bullfrog populations should never be neglected even though they are rarely captured. In addition, Gnathostoma nipponicum has also been detected in bullfrog in Japan [86].

\section{Zoonotic parasites carried by invasive alien birds}

No information about the zoonotic parasites carried by invasive alien birds is available in China, but there are a few reports about these parasites worldwide, which are listed in Table 5.

\section{Zoonotic parasites carried by invasive alien mammals} Invasive alien mammals consist of Macaca fascicularis and nine species of rodents, including 6 species of rats. Rats are the most common rodents in the communities and thus play a significant role in human health as a vector of many zoonotic pathogens, especially in the areas with high temperature and poor sanitation.

Invasion history of Rattus norvegicus, $R$. rattus and Mus musculus can't be traced because their invasion was far before the foundation of the People's Republic of China, PRC and the beginning of nationwide monitoring of rodents. Thus, with such a long history and great adaptability to all kinds of environments, they have spread all over China. A survey in Zhejiang Province showed that dominant species of rodents are $M$. musculus and $R$. norvegicus indoor and outdoor respectively [87]. And M. musculus and R. norvegicus ranked 2nd and 3rd in number of indoor rodents in Shanghai, 
Table 4 Zoonotic parasites carried by invasive alien fishes

\begin{tabular}{|c|c|c|c|}
\hline Invasive alien species & Common name & Parasites & Reference \\
\hline \multirow[t]{3}{*}{ Oncorhynchus mykiss } & \multirow[t]{3}{*}{ Rainbow trout } & Diphyllobothrium dendriticum & [76] \\
\hline & & D. latum & {$[128,129]$} \\
\hline & & Cryptosporidium sp. & [130] \\
\hline Salvelinus forntinalis & \multirow[t]{2}{*}{ Brook trout } & D. dendriticum, D. latum & [131] \\
\hline Piaractus mesopotamicus Holmberg & & Eustrongylides sp. & [78] \\
\hline \multirow[t]{4}{*}{ Gambusia affinis } & \multirow[t]{4}{*}{ Mosquitofish } & Centrocestus formosanus & {$[127,132]$} \\
\hline & & Haplorchis taichui & {$[127]$} \\
\hline & & H. yokogawai & {$[67]$} \\
\hline & & H. pumilio & {$[127,133]$} \\
\hline Stizostedion vitreum & Walleye & D. latum & [129] \\
\hline Perca flavescens & Yellow Perch & D. latum & {$[129,134]$} \\
\hline \multirow[t]{2}{*}{ Lucioperca lucioperca } & \multirow[t]{2}{*}{ Pike-perch } & Eustrongylides sp. & [135] \\
\hline & & Anisakis simplex & [136] \\
\hline Cichlasoma managuense, Parachromis managuensis & & Gnathostoma sp. & [137] \\
\hline \multirow[t]{4}{*}{ Oreochromis niloticus } & \multirow[t]{4}{*}{ Nile tilapia } & $\begin{array}{l}\text { H. pumilio, H. taichui, Procerovum varium, } \\
\text { Metagonimus spp., C. sinensis }\end{array}$ & [80] \\
\hline & & Gnathostoma sp. & [138] \\
\hline & & Cryptosporidium spp., Prohemistomum spp. & [139] \\
\hline & & C. formosanus & [140] \\
\hline \multirow[t]{2}{*}{ Oreochromis nilotica } & \multirow[t]{2}{*}{ Red tilapia } & C. philippinensis & [141] \\
\hline & & H. yokogawai & [67] \\
\hline Tilapia zillii & & $\begin{array}{l}\text { Capillaria sp., Diphyllobothrium sp., H. nana, } \\
\text { Trichostrongylus sp. }\end{array}$ & {$[142]$} \\
\hline Oreochromis sp. & & Cryptosporidium sp. & [130] \\
\hline \multirow[t]{2}{*}{ Oreochromis mossambicus } & \multirow[t]{2}{*}{ Black tilapia } & C. sinensis & {$[75,143]$} \\
\hline & & Gnathostoma sp. & [138] \\
\hline Clarias spp. & & H. pumilio & [144] \\
\hline \multirow[t]{2}{*}{$\begin{array}{l}\text { (Clarias lazera Cuvier \& Valenciennes Clarias macrocephalus } \\
\text { Günther Clarias batrachus L.) }\end{array}$} & & $\begin{array}{l}\text { H. taichui (for C. batrachus), H. yokogawai (for C. } \\
\text { batrachus) }\end{array}$ & {$[145]$} \\
\hline & & Gnathostoma spinigerum & {$[146,147]$} \\
\hline \multirow[t]{2}{*}{ Pangasius sp. } & & H. pumilio & [144] \\
\hline & & C. formosanus & [148] \\
\hline Siluris glanis & $\begin{array}{l}\text { European } \\
\text { catfish }\end{array}$ & Eustrongylides sp. & [135] \\
\hline Ictalurus punctatus & Channel catfish & Eustrongylides sp. & [149] \\
\hline \multirow[t]{2}{*}{ Channa striata } & \multirow[t]{2}{*}{ Snakehead fish } & H. pumilio, H. taichui, O. viverrini, Procerovum sp. & {$[150]$} \\
\hline & & G. spinigerum & [147] \\
\hline Channa micropeltes & & Gnathostoma sp. & [151] \\
\hline Lates calcarifer & Asian seabass & Cryptosporidium sp. & [130] \\
\hline Cirrhina mrigala/Labeo rohita & Mrigal/Rohu & $\begin{array}{l}\text { C. formosanus, C. sinensis, H. pumilio, H. taichui, H. } \\
\text { yokogawai, P. varium }\end{array}$ & {$[145,152]$} \\
\hline Cyprinus carpio var. specularis. & \multirow[t]{4}{*}{ Mirror carp } & C. sinensis & {$[75,153]$} \\
\hline \multirow[t]{3}{*}{ Cyprinus carpio var. Mirror splittered } & & C. formosanus, H. pumilio, H. yokogawai & [145] \\
\hline & & O. viverrini & [154] \\
\hline & & H. taichui & {$[127]$} \\
\hline Carassius auratus Cuvieri Temminck \& Schlegel & Japanese & C. sinensis, Centrocestus armatus, Metagonimus & {$[127]$} \\
\hline
\end{tabular}


Table 4 Zoonotic parasites carried by invasive alien fishes (Continued)

\begin{tabular}{lll}
\hline Invasive alien species & Common name & Parasites \\
\hline & crucian carp & takahashii, Metagonimus spp. \\
& Haplorchis spp. & Metorchis orientalis \\
& O. felineus & O. viverrini \\
Chalcalburnus chalcoides & H. yokogawai & Anisakis sp. \\
\hline
\end{tabular}

respectively [88]. They might be imported through ocean shipping [89]. And modern transportation may accelerate their invasion. Before the railway opened to traffic in Xinjiang Uygur Autonomous Region, there is no record of $R$. norvegicus. Since 1975 when $R$. norvegicus was first captured in a train in Xinjiang, $R$. norvegicus have dramatically expanded in local rodent population and became the dominant species in 1989 [90]. Another species of invasive alien rodent, Ondatra zibethicus, spread into China from Union of Soviet Socialist Republics through the rivers at northwestern and northeastern border [91]. Besides, Myocastor coypus was initially introduced and farmed as fur animal. But as the fur quality dropped in the farmed M. coypus in southern China, they were abandoned and became wild [92].

Heterophyids $H$. nana and $H$. diminuta are the common zoonotic intestinal parasites of wild rats. Xinjiang is a high incidence area of $H$. nana infection, where some regions can reach even $9.2 \%$. In these areas, $H$. nana infection rate is relatively high in $R$. norvegicus and $M$. musculus [93]. In addition, an average infection rate of 0.02 and $0.01 \%$ for $H$. diminuta and $H$. nana, respectively was reported in an investigation in Yunnan Province, while it was 0.1 and $0.2 \%$ in Henan Province [94, 95].

Angiostrongylus cantonensis $A$. cantonensis was first identified in the lung of $R$. rattus and $R$. norvegicus in Guangzhou in 1933. It's thought that $R$. rattus and $R$. norvegicus are the most common definitive host of $A$. cantonensis, which is indispensable for the establishment of its foci [96]. The presence of this parasite in rats indicates that this region is endemic. $R$. norvegicus, $R$. tanezumi had been reported to harbor this parasite in China [97].

Babesia microti There are many natural foci of Babesia microti in China and several sporadic cases of human infection have been reported in 8 PAM [98]. A case of human babesiosis was reported in Zhejiang Province in 2012 , and the local investigation found B. microti infection in two $R$. tanezumi and one $R$. norvegicus [99].

Echinococcus multilocularis Echinococcus multilocularis is endemic in northwest China, mainly Xinjiang, Ningxia, Gansu, Sichuan and Qinghai, where there are still many semi-nomads. Over 1000 cases of alveolar echinococcosis caused by E. multilocularis had been reported in China from 1956 to 2005 [100]. In Xinjiang, E. multilocularis was detected in $R$. norvegicus and $M$. musculus [100, 101]. However, the infection rate of $E$. multilocularis might have been underestimated a lot, as about 200 cases were reported just in the First affiliated hospital of Xinjiang Medical University [102]. The low infection rate reported may be attributed to the underdevelopment of those regions and limit of their technology of diagnosis.

Table 5 Zoonotic parasites carried by invasive alien birds

\begin{tabular}{llll}
\hline Species & Common name & Parasites & Reference \\
\hline Psittacula krameri & Ring-necked parrot & Cryptosporidium meleagridisin & {$[158]$} \\
Branta canadensis & Canadian goose & Cryptosporidium parvum & {$[159,160]$} \\
& & Toxoplasma gondii & {$[161]$} \\
& & C. hominis & [162] \\
& & Giardia sp. & Trichobilharzia spp. \\
\hline
\end{tabular}


Table 6 Zoonotic parasites carried by invasive alien mammals

\begin{tabular}{|c|c|c|c|}
\hline Invasive alien species & Common name & Parasites & Reference \\
\hline \multirow[t]{17}{*}{ Rattus norvegicus } & \multirow[t]{17}{*}{ Wild brown rats } & Angiostrongylus cantonensis & {$[19,106,164-167]$} \\
\hline & & Echinococcus multilocularis & [168] \\
\hline & & Capillaria hepatica, Hymenolepis diminuta, Taenia taeiaeformis & [169] \\
\hline & & Schistosoma mansoni, Moniliformis moniliformis & [170] \\
\hline & & H. nana, Giardia sp., Cryptosporidium sp., Entamoeba sp. & [171] \\
\hline & & C. parvum & [172] \\
\hline & & Entrobius spp., Trichuiris spp. & [173] \\
\hline & & Leishmania major & [174] \\
\hline & & L. infantum & [175] \\
\hline & & Toxoplasma gondii & [161] \\
\hline & & Trichinella spiralis, T. britovi, T. pseudospiralis & [176] \\
\hline & & Toxocara canis & [177] \\
\hline & & Gongylonema pulchrum & [178] \\
\hline & & Syphacia muris & [179] \\
\hline & & Sarcocystis orientalis & [180] \\
\hline & & $\begin{array}{l}\text { Paragonimus westermani, Plagiorchis potamonides, Echinostoma } \\
\text { ilocanum, Raillietina madagascariensis }\end{array}$ & [181] \\
\hline & & S. japonicum & [182] \\
\hline \multirow[t]{13}{*}{ Rattus rattus } & \multirow[t]{13}{*}{ House rat/Roof rat } & Rictularia sp., H. diminuta, M. moniliformis & [168] \\
\hline & & C. parvum & [183] \\
\hline & & Fasciola hepatica & [184] \\
\hline & & Taenia taeniaeformis & [185] \\
\hline & & Leishmania donovani donovani, L. donovani infantum & [186] \\
\hline & & A. cantonensis & [166] \\
\hline & & G. pulchrum & [178] \\
\hline & & T. britovi & [176] \\
\hline & & T. gondii & [187] \\
\hline & & Sc. mansoni & [188] \\
\hline & & Sarcocystis sp. & [180] \\
\hline & & Babesia microti & [98] \\
\hline & & T. spiralis, Entamoeba coli, Dientamoeba fragilis & [189] \\
\hline \multirow[t]{11}{*}{ Mus musculus } & \multirow[t]{11}{*}{ House mouse } & Enterocytozoon bieneusi & [190] \\
\hline & & C. hepaticum & [191] \\
\hline & & C. parvum & [183] \\
\hline & & H. nana & [192] \\
\hline & & H. diminuta, S. muris, T. taeniaeformis & [193] \\
\hline & & Leishmania major & [194] \\
\hline & & A.s cantonensis & [195] \\
\hline & & H. taichui & [196] \\
\hline & & T. gondii & [197] \\
\hline & & T. canis & [198] \\
\hline & & E. multilocularis & [199] \\
\hline \multirow[t]{2}{*}{ Rattus tanezumi Temminck } & \multirow[t]{2}{*}{ Asian house rats } & A. cantonensis, Hymenolepis spp., T. taeniaeformis & [200] \\
\hline & & Syphacia muris, H. diminuta & [201] \\
\hline
\end{tabular}


Table 6 Zoonotic parasites carried by invasive alien mammals (Continued)

\begin{tabular}{|c|c|c|c|}
\hline Invasive alien species & Common name & Parasites & Reference \\
\hline & & T. gondii & {$[202]$} \\
\hline & & C. hepaticum & [203] \\
\hline & & B. microti & [98] \\
\hline & & $\begin{array}{l}\text { Artyfechinostomum malayanum, Echinostoma ilocanum, E. } \\
\text { lindoense, H. nana, M. moniliformis, P. westermani, Plagiorchis } \\
\text { muris, P. philippinensis, P. potamonides, Raillietina } \\
\text { madagascariensis, S. japonicum, T. taeniaeformis }\end{array}$ & [181] \\
\hline \multirow[t]{4}{*}{ Rattus exulans } & Pacific rats & S. japonicum & [182] \\
\hline & & H. diminuta, H. nana, M. moniliformis, Raillietina spp. & [204] \\
\hline & & A. cantonensis & [19] \\
\hline & & T. gondii & [205] \\
\hline \multirow[t]{4}{*}{ Ondatra zibethicus } & Musk rat & E. multilocularis & [206] \\
\hline & & Taenia martis, T. taeniaeformis & [207] \\
\hline & & C. hepatica & [208] \\
\hline & & C. parvum & [183] \\
\hline \multirow[t]{6}{*}{ Myocastor coypus } & Nutria & C. parvum & [183] \\
\hline & & T. gondii & [209] \\
\hline & & E. multilocularis & [206] \\
\hline & & F. hepatica & [210] \\
\hline & & Strongyloides myopotami & [211] \\
\hline & & C. hepatica & [212] \\
\hline \multirow[t]{3}{*}{ Sciurus vularis exalbidus } & Red squirrek & T. gondii & [213] \\
\hline & & C. hepaticum & [203] \\
\hline & & C. parvum & [166] \\
\hline \multirow[t]{3}{*}{ Callosciurus erythraeus } & Red-bellied squirrel & Hymenolepis sp. & [214] \\
\hline & & E. bieneusi & [164] \\
\hline & & A. cantonensis & {$[215]$} \\
\hline \multirow[t]{11}{*}{ Macaca fascicularis } & & C. parvum & [216] \\
\hline & & Plasmodium knowlesi & {$[200,217]$} \\
\hline & & E. histolytica & [218] \\
\hline & & Endolimax nana, Oesophagostomum & [219] \\
\hline & & Sarcocystis sp. & [220] \\
\hline & & Strongyloides fulleborni & [221] \\
\hline & & H. nana, Strongyloides spp. & [222] \\
\hline & & Armillifer agkistrodontis & [223] \\
\hline & & G. duodenalis & [224] \\
\hline & & T. trichiura & [225] \\
\hline & & E. multilocularis & [226] \\
\hline
\end{tabular}

Capillaria hepatica C. hepatica is a rare zoonotic parasite with only three cases of human infection reported in China [103]. So far, only one case of C. hepatica infection in human has been reported in Fujian Province. However, a local investigation revealed a high infection rate, 10.8 and $7.7 \%$ respectively in $R$. norvegicus and $M$. musculus [104].
C. sinensis $O$. zibethicus, $R$. norvegicus and $M$. musculus can serve as the reservoir host of $C$. sinensis in China [105].

As being estimated, rodents are vectors of at least 60 zoonotic diseases [106]. While researches on the zoonotic parasites carried by these alien invasive rodents are limited in China, many globally reported parasites are not detected, which are listed in Table 6 . 


\section{Prevention and control}

The invasion of alien species becomes much more common with predictable developing international communications and inevitable globalization [107]. Considering the great damage it may cause [108], the Chinese government has focused on the administration, international cooperation, fundamental researches and public awareness to cope with the problems [109]. The Ministry of Agriculture (MOA) has established the institution for administration of invasive alien species and a center for management of invasive alien species. MOA also organized to draw up the Measures for Management of IAS, rectified the Contingency Plans for Emergency of Alien Species Invasion, perfect the database of IAS in China and complete the prevention and control system. The Chinese government has put up some relevant legislation including Law of the RPC on the Entry and Exit Animal and Plant Quarantine against the IAS in 1996 [110], and the science funding regarding associated programs are booming as well [109].

However, the Chinese government should also issue more regulations to complete the legislation system toward the IAS and the current regulations should be enforced strictly. Surveillance and prevention system should be improved, and some cross-industry obligatory institutions should be established to integrate related work to fulfill the administration. The propagation of science knowledge should also be intensified to raise public awareness of the IAS.

For those species introduced deliberately as food material, the China Food and Drug Administration (CFDA) is supposed to take rigid strategy to restrict the introduction and make rigorous standard to ensure the safety and harmlessness of the species. For those IAS which entered China coincidentally, related institutions at the national border should intensify the surveillance and monitor system to prevent the invasion of unwanted species. For some IAS which have the potential to cause or has already caused enormous economic, environmental or public health problems, some eradication steps are supposed to be considered to prevent further loss.

\section{Conclusions}

It can be predicted that the IAS issue may become a progressively important problem globally with the

Table 7 Reported distribution and case reports of zoonotic parasites carried by invasive alien species in China

\begin{tabular}{|c|c|c|c|c|c|}
\hline Parasites & Location of report & $\begin{array}{l}\text { Reported local invasive } \\
\text { alien host }\end{array}$ & $\begin{array}{l}\text { Infection rate in investigated } \\
\text { population }\end{array}$ & $\begin{array}{l}\text { Number of } \\
\text { Case reports }\end{array}$ & Reference \\
\hline $\begin{array}{l}\text { Angiostrongylus } \\
\text { cantonensis }\end{array}$ & $\begin{array}{l}\text { Yunnan, Guangxi, Hainan, Guangdong, } \\
\text { Fujian, Zhejiang, Jiangsu, Beijing, Tianjin, } \\
\text { Liaoning, Heilongjiang. }\end{array}$ & $\begin{array}{l}\text { Rattus rattus, } R \text {. norvegicus, } \\
\text { Pomacea canaliculate, } \\
\text { Achatina fulica }\end{array}$ & - & 334 & {$[34,96]$} \\
\hline $\begin{array}{l}\text { Paragonimus } \\
\text { westermani }\end{array}$ & $\begin{array}{l}\text { Hunan, Liaoning, Jilin, Heilongjiang, } \\
\text { Sichuan, Yunnan, Shanxi, Zhejiang, } \\
\text { Henan, Hubei, Hebei, Shaanxi, Gansu, } \\
\text { Anhui, Guizhou, Guangdong, Hainan, } \\
\text { Jiangxi, Fujian }\end{array}$ & Procambarus clarkii & $1.71 \%$ & - & {$[47,48]$} \\
\hline Haplorchis taichui & Guangxi & Cyprinus carpio, C. auratus & $\begin{array}{l}24.3-90.5 \% \text { (in people with a } \\
\text { habit of consuming raw fish) }\end{array}$ & - & {$[70]$} \\
\hline Clonorchis sinensis & $\begin{array}{l}\text { Guangdong, Guangxi, Heilongjiang, } \\
\text { Jilin, Liaoning, Hunan, Chongqing, } \\
\text { Jiangsu, Anhui, Fujian, Hainan, Tianjin, } \\
\text { Sichuan, Henan, Shandong, Hubei, } \\
\text { Guizhou, Xinjiang, Hebei, Jiangxi, } \\
\text { Shanghai, Shanxi, Beijing, Yunnan, } \\
\text { Shanxi, Gansu, Zhejiang }\end{array}$ & $\begin{array}{l}\text { C. auratus, C carpio, } O \text {. } \\
\text { mossambica }\end{array}$ & $\begin{array}{l}\text { 2.4\% (about } 12.5 \text { million } \\
\text { people) }\end{array}$ & - & {$[73-75]$} \\
\hline $\begin{array}{l}\text { Diphyllobothrium } \\
\text { latum }\end{array}$ & Taiwan, Heilongjiang, Jilin & $\begin{array}{l}\text { Oncorhynchus mykiss, } \\
\text { Salvelinus forntinalis, } \\
\text { Stizostedion vitreum, Perca } \\
\text { flavescens }\end{array}$ & - & 16 & {$[77]$} \\
\hline Gnathostoma spp. & $\begin{array}{l}\text { Zhejiang, Jiangsu, Anhui, Hunan, } \\
\text { Hubei, Shandong, Henan, Jiangxi, } \\
\text { Guangdong, Hainan, Taiwan, Fujian, } \\
\text { Shanghai, Jilin, Heilongjiang, Xinjiang }\end{array}$ & C. carpio, C. auratus & - & $\begin{array}{l}\text { More than } \\
50\end{array}$ & {$[79]$} \\
\hline Babesia microti & $\begin{array}{l}\text { Chongqing, Yunnan, Inner Mongolia, } \\
\text { Taiwan, Zhejiang, Shandong, Shanxi, } \\
\text { Xinjiang }\end{array}$ & R. tanezumi, R. norvegicus & - & 27 & {$[98]$} \\
\hline $\begin{array}{l}\text { Echinococcus } \\
\text { multilocularis }\end{array}$ & $\begin{array}{l}\text { northwest China, mainly Xinjiang, } \\
\text { Ningxia, Gansu, Sichuan and Qinghai }\end{array}$ & R. norvegicus, M. musculus & - & Over 1000 & [100-102] \\
\hline Capillaria hepatica & - & R. norvegicus, M. musculus & - & 3 & {$[103,104]$} \\
\hline
\end{tabular}


development of society and booming international communication. The government should raise awareness of the possible destructions the IAS may cause and take some measures in advance to prevent possible loss.

Apart from IAS's direct damage to the ecology and economy, its capability as the vector to transmit parasitic disease should arouse public awareness. In China, as mentioned above, many species may play an important role in the transmission of some specific diseases, but the relative researches are rather scarce which suggests insufficient emphasis regarding such an issue. The risk of the parasites carried by the IAS is vastly underestimated. With various climates and multiple landforms, China is suitable for numerous IAS and parasites to settle down. However, few associated reports or researches can be found in China, as most case reports of zoonotic parasites carried by invasive alien species in China were listed in Table 7. More efforts about associated problems should be paid in both researching and administration. For those species which has already caused some zoonotic diseases, compulsory measures to control the species should be conducted to ensure the safety of public and some eradication methods ought to be considered for some more dangerous disease. For those species capable of transmitting parasites with no specific case reported yet, the screening surveys and control measures should be strictly fulfilled periodically to guarantee the safety of those species.

\section{Additional file}

Additional file 1: Multilingual abstracts in the five official working languages of the United Nations. (PDF $602 \mathrm{~kb}$ )

\section{Acknowledgements}

We warmly thank Prof. Ming-Chiu Fung and Dr. Yawar Abbas for this manuscript polishing.

\section{Funding}

This work was supported by grants from the National Key Research and Development Program of China (grant No. 2016YFC1202003, 2016YFC1202005 and 2016YFC1200500), the Project of Basic Platform of National Science and Technology Resources of the Ministry of Sciences and Technology of China (grant No. TDRC-2017-22), the National Natural Science Foundation of China (grant No. 81371836, 81572023 and 81271855), Guangdong Natural Science Foundation (grant No. 2014A030313134), Science and Technology Planning Project of Guangdong Province (grant No. 2016A050502008), Science and Technology Planning Project of Guangzhou (grant No. 201607010029), the 111 Project (grant No. B12003), the Undergraduates Innovation Training Program of Guangdong Province (grant No. 201410558274 and 201601084) and Teaching Reform Project of Sun Yat-sen University (grant No. 2016012).

\section{Availability of data and materials}

The datasets used and/or analysed during the current study are available from the corresponding author on reasonable request.

\section{Authors' contributions}

ZGL, TYY, YL and WZD carried out the literature search and drafted the first version of the manuscript. $L J$ and $L Z Y$ were responsible for designing, coordinating and revising the review. All authors read and approved the final manuscript.

Ethics approval and consent to participate

Not applicable.

Consent for publication

Not applicable.

\section{Competing interests}

The authors declare that they have no competing interests.

\section{Author details}

'Zhongshan School of Medicine, Sun Yat-sen University, Guangzhou 510080, China. ${ }^{2}$ Fifth Affiliated Hospital, Sun Yat-sen University, Zhuhai 519000, Guangdong, China. ${ }^{3}$ Key Laboratory of Tropical Disease Control, Ministry of Education, Sun Yat-sen University, Guangzhou 510080, China. ${ }^{4}$ Provincial Engineering Technology Research Center for Biological Vector Control, Guangzhou 510080, China. ${ }^{5}$ Faculty of Tropical Medicine, Mahidol University, Bangkok 10400, Thailand.

Received: 8 August 2018 Accepted: 18 December 2018

Published online: 09 January 2019

\section{References}

1. Pejchar L, Mooney HA. Invasive species, ecosystem services and human well-being. Trends Ecol Evol. 2009:24:497-504.

2. Wilcove DS, Rothstein D, Dubow J, Phillips A, Losos E. Quantifying threats to imperiled species in the United States. Bioscience. 1998:48:607-15.

3. Pimentel D, Zuniga R, Morrison D. Update on the environmental and economic costs associated with alien-invasive species in the United States. Ecol Econ. 2005:52:273-88.

4. Liu TT, Zhang HJ, Ma ZY. Assessment of economic damage from biological invasion. Ecol Econ. 2010:02:173-5 (in Chinese)

5. Zhang R, Li Y, Liu N, Porter SD. An overview of the red imported fire ant (hymenoptera : Formicidae) in mainland China. Fla Entomol. 2007; 90:723-31.

6. Xu H, Qiang S, Genovesi P, Ding H, Wu J, Meng L, et al. An inventory of invasive alien species in China. NeoBiota. 2012;15:1-26.

7. Wan $F$, Jiang $M$, Zhan A. Biological invasions and its management in china. Berlin: Springer Netherlands; 2017.

8. Kelly DW, Paterson RA, Townsend CR, Poulin R, Tompkins DM. Parasite spillback: a neglected concept in invasion ecology? Ecology. 2009;90: 2047-56.

9. Pysek P, Richardson DM. Invasive species, environmental change and management, and health. Ann Rev Environ Res. 2010;35:25-55.

10. Li XH, Hu YC, Song HM, Wang PZ, Wang XJ, Mou XD, et al. Invasion and monitoring methods of Pomacea canaliculata for in China. Chin Agri Sci Bull. 2009;25:229-32 (in Chinese).

11. Wang Q, Chen X, Lun Z. Invasive fresh water snail, China. Emerg Infect Dis. 2007:13:1119

12. Yang $Y X, H u Y C, L i X H$, Wang $X J$, Mou XD, Song HM, et al. Historical invasion, expansion process and harm investigation of Pomacea canaliculate in China. Chin Agri Sci Bull. 2010;26:245-50 (in Chinese).

13. Zhang HT, Luo D, Mou XD, Xu M, Wei H, Luo JR, et al. Predicting the potential suitable distribution area of the apple snail Pomacea canaliculate in China based on multiple ecological niche models. Chin J Appl Ecol. 2016; 27:1277-84 (in Chinese).

14. Ye J. FYLX. Host plants and their effects on body mass in the golden apple snail, Pomacea canaliculata Lamarck. J Biosafe. 2011;20:124-31.

15. Horgan FG, Stuart AM, Kudavidanage EP. Impact of invasive apple snails on the functioning and services of natural and managed wetlands. Acta Oecol. 2014:54:90-100

16. Carlsson N, Brönmark C, Hansson L-A. Invading herbivory: the golden apple snail alters ecosystem functioning in Asian wetlands. Ecology. 2004;85:1575-80.

17. Damborenea C, Brusa F, Negrete L. Symbionts and diseases associated with invasive apple snails. In: Biol Manage Invasive Apple Snails; 2017. p. 73-97.

18. Pien FD, Pien $\mathrm{BC}$. Angiostrongylus cantonensis eosinophilic meningitis. Int J Infect Dis. 1999;3:161-3. 
19. Wang $Q P$, Lai $D H$, Zhu $X Q$, Chen $X G$, Lun ZR. Human angiostrongyliasis. Lancet Infect Dis. 2008;8:621-30.

20. Rosen L, Laigret J, Bories S. Observations on an outbreak of eosinophilic meningitis on Tahiti, French Polynesia. Am J Hyg. 1961;74:26-42.

21. Chen XG, Li H, Lun ZR. Angiostrongyliasis, mainland China. Emerg Infect Dis. 2005;11:1645-7.

22. Lv S, Zhang Y, Steinmann P, Zhou X. Emerging angiostrongyliasis in mainland China. Emerg Infect Dis. 2008;14:161-4.

23. Lv S, Zhang Y, Liu HX, Hu L, Yang K, Steinmann P, et al. Invasive snails and an emerging infectious disease: results from the first national survey on Angiostrongylus cantonensis in China. PLoS Negl Trop Dis. 2009;3:e368.

24. Graczyk TK, Fried B. Echinostomiasis: a common but forgotten food-borne disease. Am J Trop Med Hyg. 1998;58:501-4.

25. Wang TP, Yuan HC, Xu FN. Current research status on human echinostomiasis. Chin J Parasit Dis Contrl. 1995;13:119-25 (in Chinese).

26. Li X. Food-borne parasitic zoonoses in the People's Republic of China. Southeast Asian J Trop Med Public Health. 1991;Suppl:31-5.

27. Komalamisra C, Nuamtanong S, Dekumyoy P. Pila ampullacea and Pomacea canaliculata, as new paratenic hosts of Gnathostoma spinigerum. Southeast Asian J Trop Med Public Health. 2009;40:243-6.

28. Gao ST. Epidemiology, clinical picture, diagnosis and treatment of gnathostomiasi. Chin Trop Med. 2014;14:1136-9 (in Chinese).

29. Jarrett VHC. The spread of the snail Achatina fulica to south China. Hong Kong Naturalist. 1931;il:262-4.

30. Wang CB. Current research status on African giant snail. J Shanghai Agri Sci Tech. 2011;41:22-3 (in Chinese).

31. Guo J, Zhang JE, Wu RS, Zhao BL, Yang HR. Overview and perspective on the current research status for the giant snail Achatina fulica in China. Guangxi Agric Sci. 2015;04:626-30 (in Chinese).

32. Li P, Li Y. Research on the establishment and prevention of Achantina fulica in Yunnan province. J Yunnan Univ. 2008:51:203-5 (in Chinese).

33. Thiengo SC, Maldonado A, Mota EM, Torres EJEL, Caldeira R, Carvalho ODS, et al. The giant African snail Achatina fulica as natural intermediate host of Angiostrongylus cantonensis in Pernambuco, Northeast Brazil. Acta Trop. 2010;115:194-9.

34. Huang D, Song JQ, Ye J, Cai ZW, Liu SJ, Qian LY, et al. Study of Angiostrongylus cantonensis infection on Achatina fulica and Ampullaria gigas from Jiangmen City of Guangdong Province. Prev Med Tribune. 2007; 13:966-8 (in Chinese).

35. Carvalho ODS, Teles HAC, Mota EM, CLAG MCCA, Lenzi HL. Potentiality of Achatina fulica Bowdich, 1822 (Mollusca: Gastropoda) as intermediate host of the Angiostrongylus costaricensis Morera \& Cespedes 1971. Rev Soc Bras Med Trop. 2003;36:743-5.

36. Callisto M, Moreno P, Alves Jr JF GCC, Ferreira WR, Gomes C. Malacological assessment and natural infestation of Biomphalaria straminea (dunker, 1848) by Schistosoma mansoni (Sambon, 1907) and Chaetogaster limnaei (K. Von Baer, 1827) in an urban eutrophic watershed. Braz J Biol. 2005;65:217-28.

37. Woodruff DS, Mulvey M, Yipp MW. Population genetics of Biomphalaria straminea in Hong Kong: a neotropical schistosome-transmitting snail recently introduced into China. J Hered. 1985;76:355-60.

38. Huang SY, Zhang QM, Li XH, Zhuo H. Distribution and schistosomiasis transmission risks of Biomphalaria straminea in inland China. Zhongguo Xue Xi Chong Bing Fang Zhi Za Zhi. 2014;26:235-7 (in Chinese).

39. Yi P, Yuan $L H$, Wang ZH, He YK, Jing QS, Zhou J, et al. Retrospective survey of 184 patients infected with Schistosoma haematobium from African countries. Zhongguo Xue Xi Chong Bing Fang Zhi Za Zhi. 2011;23:441-2 (in (hinese).

40. Zhu R, Xu J. Epidemic situation of oversea imported schistosomiasis in China and thinking about its prevention and control. Zhongguo Xue Xi Chong Bing Fang Zhi Za Zhi. 2014;26:111-4 (in Chinese).

41. Lima MG, Tunholi-Alves VM, Gaudêncio FN, Martins FG, Castro RN, Thiengo SC, Garcia JS, Maldonado A Jr, Pinheiro J. The influence of Angiostrongylus cantonensis (Nematoda, Metastrongylidae) infection on the aerobic metabolism of Biomphalaria straminea and Biomphalaria tenagophila (Mollusca, Gastropoda). Exp Parasitol. 2016;171:1-9.

42. Siesa ME, Manenti R, Padoa-Schioppa E, De Bernardi F, Ficetola GF. Spatial autocorrelation and the analysis of invasion processes from distribution data: a study with the crayfish Procambarus clarkii. Biol Invasion. 2011;13:2147-60.

43. Wang W, Gu W, Ding Z, Ren Y, Chen J, Hou Y. A novel Spiroplasma pathogen causing systemic infection in the crayfish Procambarus clarkii (Crustacea: decapod), in China. FEMS Microbiol Lett. 2005;249:131-7.
44. Liu QG, Li YS, Chen LS. The biology of Procambarus Clarkii. Fish Sci Tech Inform. 2008;36:21-3 (in Chinese).

45. Xu JT, Yan BL, Xu GC. The background of development, current status and prospection of the industry of Procambarus Clarkii. Fish Sci Tech Inform. 2011;39:172-6 (in Chinese).

46. Chiu J. Intermediate hosts of Paragonimus westermanii at Shen-Keng District of Taipei County, Taiwan (Formosa). J Parasitol. 1962;48:423-6.

47. Liu Q, Wei F, Liu W, et al. Paragonimiasis: an important food-borne zoonosis in China. Trends Parasitol. 2008;24(7):318-23.

48. Hu YH, Zhan X. Diagnosis and treatment progress of paragonimiasis. Chin J Clinicians (Electronic Edition). 2017;11:849-54.

49. Chen L, Lu D, Xu L, Cao CL, Zhong B. Endemic situation and tendency of Paragonimus, Sichuan Province. Modern Prev Med. 2015;23:4230-3 (in Chinese).

50. Prates HT, Santos JP, Waquil JM, Fabris JD, Oliveira AB, Foster JE. Insecticidal activity of monoterpenes against Rhyzopertha dominica (F.) and Tribolium castaneum (Herbst). J Stored Prod Res. 1998:34:243-9.

51. Zhang T. Geographical distribution, spread pathway and biological control techniques of predatory mites of Tribolium castaneum (Herbst) (Coleoptera: Tenebrionidae). Beijing: Chinese Agricultural University; 2017. (in Chinese)

52. Zhang T, Wu Y, Liu $\sqcup$, Zhao ZH, Wang ZM, He PH, et al. Research on the geographical distribution of Tribolium Castaneum (Herbst) in China. J Chin Cereal Oil Ass. 2018:33:70-5 (in Chinese).

53. Taijing J, Zhehao J, Hui W, Chunquan C. A study on the life-cycle and epidemiology of Pseudanoplocephala crawfordi Baylis, 1927. J Helminthol. 1990;64:54-61.

54. Jia Y, Yan W, Du S, Song J, Zhao W, Zhao Y, et al. Pseudanoplocephala crawfordi is a member of genus Hymenolepis based on phylogenetic analysis using ribosomal and mitochondrial DNA sequences. Mitochondrial DNA A DNA Mapp Seq Anal. 2016;27(3):1688-92.

55. Han LF, Yan WC, Wang TQ, Wu L, Wang PL. Preparation of stained specimens for the adult of Pseudanoplocephala crawfordi and its structural observation. Chin Agri Bull. 2012;29:248-52 (in Chinese).

56. Wu F, Jin XX, Mao FR, Cui J. One case report of human psudanoplocephalosis. J Henan Med Univ. 2000;67:156 (in Chinese).

57. Li G, Zhang YS, Wei HQ. The life cycle and classification of Pseudanoplocephala crawfordi Baylis, 1927. Acta Vet Zootech Sin. 1982;13: 29-35 (in Chinese).

58. Huo XB. Invasion of Blattella germanica and its infestation management in urban environment in China. Chin J Vector Biol Contrl. 2015;26:114-6 (in Chinese).

59. Pai HH, Ko YC, Chen ER. Cockroaches (Periplaneta americana and Blattella germanica) as potential mechanical disseminators of Entamoeba histolytica. Acta Trop. 2003;87:355-9.

60. Srivastava D, Mehta AK, Arora N, Gaur SN, Singh BP. Proteolytically inactive per a 10 allergen of Periplaneta americana modulates Th2 response and enhances IL-10 in mouse model. J Clin Immunol. 2010:30:426-34.

61. Lou YD. Present situation and countermeasure of the study on fish introduction in China. J Fish Chin. 2000;24:185-92 (in Chinese).

62. Pan Y. History and approach of invasion from domestic and abroad fishes. $J$ Dalian Fish Univ. 2006;27:72-8 (in Chinese).

63. Tan Y. The status of the exotic aquatic organisms in China. In: Exotic aquatic organisms in Asia, Proceedings of the Workshop on Introduction of Exotic Aquatic Organisms in Asia; 1989. p. 35-43.

64. WHO. Report of the joint WHO/FAO workshop on foodborne trematode infections in Asia, Hanoi, Vietnam, 26-28 Nov 2002. Manila: WHO Regional Office for the Western Pacific; 2004.

65. Qiu J, Zhang Y, Zhang X, Gao Y, Li Q, Chang Q, et al. Metacercaria infection status of fishborne zoonotic trematodes, except for Clonorchis sinensis in fish from the Heilongjiang Province. China Foodborne Pathog Dis. 2017;14:440-6.

66. Anh NTL, Phuong NT, Johansen MV, Murrell KD, Van PT, Dalsgaard A, et al Prevalence and risks for fishborne zoonotic trematode infections in domestic animals in a highly endemic area of North Vietnam. Acta Trop. 2009:112:198-203.

67. Chai J, Jung B. Fishborne zoonotic heterophyid infections: an update. Food Waterborne Parasitol. 2017:8-9:33-63.

68. Zhang HM. A survey on the heterophid trematodes metacercariae carried by fresh water fishes in Guangxi. Chin J Zoono. 2006;22:111-3 (in Chinese).

69. Cheng YZ, Xu GF, Guo ZF, Zeng HY, Feng ZH, Xu XR, et al. Study on natural infection of Heterophyid Pumilio in human and investigation on its fishes intermediate hosts. Strait J Prev Med. 1996;2:7-8. 
70. Yichao Y, Xueming L, Shulin L, Hongbo X, Qinhua W. Study on human infection of Haplorchis taichi in Guangxi Province, Collection of Abstracts from National Academic Conference of Parasitology and Tropical Medicine; 2008. p. 101-2. (in Chinese)

71. Nishigori M. On a new trematode Stamnosoma formosanum n. sp. and its development. Taiwan Igakkai Zasshi. 1924;234:181-228.

72. Pakharukova MY, Mordvinov VA. The liver fluke Opisthorchis felineus: biology, epidemiology and carcinogenic potential. Trans R Soc Trop Med Hyg. 2016; 110:28-36.

73. Fang YY, Chen YD, Li XM, Wu J, Zhang QM, Ruan CW. Current prevalence of Clonorchis sinensis infection in endemic areas of China. Zhongguo Ji Sheng Chong Xue Yu Ji Sheng Chong Bing Za Zhi. 2008;26:99-103 (in Chinese)

74. Liu YS. The achievements and experience of clonorchiasis control in China Zhongguo Ji Sheng Chong Xue Yu Ji Sheng Chong Bing Za Zhi. 1999;17: 17-9 (in Chinese).

75. Lun ZR, Gasser RB, Lai DH, Li AX, Zhu XQ, Yu XB, et al. Clonorchiasis: a key foodborne zoonosis in China. Lancet Infect Dis. 2005:5:31-41.

76. Kuchta R, Brabec J, Kubackova P, Scholz T. Tapeworm Diphyllobothrium dendriticum (Cestoda)-neglected or emerging human parasite? PLoS Negl Trop Dis. 2013;7:e253512.

77. Guo AJ, Liu K, Gong W, Luo XN, Yan HB, Zhao SB, et al. Molecular identification of Diphyllobothrium latum and a brief review of diphyllobothriosis in China. Acta Parasitol. 2012;57:293-6.

78. Eiras JC, Pavanelli GC, Takemoto RM, Yamaguchi MU, Karkling LC, Nawa Y. Potential risk of fish-borne nematode infections in humans in Brazil--current status based on a literature review. Food Waterborne Parasitol. 2016;5:1-6.

79. Wu HF, Zhang HM. Advances on Gnathostomiasis. Appl PrevMed. 2009;6: 380-3 (in Chinese).

80. Li K, Clausen JH, Murrell KD, Liu L, Dalsgaard A. Risks for fishborne zoonotic trematodes in Tilapia production systems in Guangdong province, China. Vet Parasitol. 2013;1-2:223-9.

81. Corkum KC. Sparganosis in some vertebrates of Louisiana and observations on a human infection. J Parasitol. 1966;52:444-8.

82. Miyazaki I, et al. An Illustrated Book of Helminthic Zoonoses. Tokyo: International Medical Foundation of Japan, Section III. Nematode Zoonoses; 1991. p. 207-14.

83. Feng JP, Hong Q, Liu HJ, Li XM, Gong LR. Sparganum infection in frogs and the source tracing, Guangzhou, China. Chin J Zoonoses. 2015;31:88-91 (in Chinese).

84. Zhang HF, Wang GH, Liu B, Qian H, Guo MJ, Wu YX. Survey of Sparganum mansoni infection in frogs and snakes and people's awareness in Tongxiang,Zhejiang province. Dis Surveillance. 2018;33:172-4 (in Chinese).

85. Wu WM, Tang Y, Wang J, Yang Y, Fang SY, Zhu SJ. Survey of Sparganum mansoni infection in frogs and snakes in Hangzhou. Dis Surveilance. 2009; 24:612-3 (in Chinese).

86. Oyamada T, Hirata T, Hara M, Kudo N, Oyamada T, Yoshikawa H, et al. Spontaneous larval Gnathostoma nipponicum infection in frogs. J Vet Med Sci. 1998;60:1029-31.

87. Gong ZY, Hou J, Fu GM, Ling F, He F, Ren ZY, et al. Rodent population density and seasonal fluctuation in Zhejiang in 2010. Chin J Vector Biol Contrl. 2012;23:244-5 (in Chinese).

88. Qian GZ, Zhu LB. An ecological study of rodents from Shanghai. Zool Res. 1983;4:339-44 (in Chinese).

89. Fan DH. Black rat found in the boatyard of Dalian Marine University. Chin J Vector Biol Control. 2000;16:282-3 (in Chinese).

90. Li W. Study on the present of migration rodent-_Brown rat (Rattus norvegicus) in Xinjiang. Chin J Vector Biol Control. 1994;10:31-3 (in Chinese).

91. Dasheng C. Discussion on the origin of muskrat in Xinjiang. Wildlife. 1986:5:52.

92. Xu RQ. The new harmful farmland animal nutria. Plant Prot. 1997;35:46-7 (in Chinese).

93. Li BS, Liu YH, Liu Y, Luo WP, Tong SX. Sophia. Preliminary studies on the correlativity of Hymenolepis nana and Hymenolepis murina infection in rural communities, Xinjiang. Endemic Dis Bull. 2003;18(\$1):15-7 (in Chinese).

94. Zhang LL, Yang JL, Yang HM, Wang YK, Yu H, Zhang L, et al. A survey of human tapeworm infections in Yunnan Province. Zhongguo Ji Sheng Chong Xue Yu Ji Sheng Chong Bing Za Zhi. 1994;12(S1):142-4 (in Chinese).

95. Chang J, Shang LY, Zhao QF. Survey of human parasite dirtribution in Henan province. Zhongguo Ji Sheng Chong Xue Yu Ji Sheng Chong Bing Za Zhi. 1991:9(S1):68-71 (in Chinese).

96. Tang JQ. Nature-borne diseases. Beijing: Science Press; 2006. p. 1182-9.
97. Li LS, Zhou XN, Lin JX, Zhang Y, Cheng YZ, Zhang RY, et al. Discovery of the new hosts for six species of Angiostrongylus cantonensis and investigation on the epidemic foci in Fujian province. Chin J Zoonoses. 2006;22:533-7 (in (hinese).

98. Zhou X, Xia S, Huang J, Tambo E, Zhuge H, Zhou X. Human babesiosis, an emerging tick-borne disease in the People's Republic of China. Parasit Vectors. 2014;7:509.

99. Yao LN, Ruan W, Zeng CY, Li ZH, Zhang X, Lei YL, et al. Pathogen identification and clinical diagnosis for one case infected with Babesia. Zhongguo Ji Sheng Chong Xue Yu Ji Sheng Chong Bing Za Zhi. 2012;30: 118-21 (in Chinese).

100. Lin YG, Lu MK. A review of current status of Echinococcus and hydatid disease with notes on some informative achievements in China. Chin J Zoonoses. 2012;28:616-27 (in Chinese).

101. Xiao $Y X, X u X L$, Yin $X P$, Wang $A D$, Yan $Z X$. Investigation on echinococcosis in wild rodents at ala-shankou port. Acta Vet Et Zootech Sin. 2015;60:100410 (in Chinese).

102. Wen H, Xu MQ. Pratical hydatid disease. Beijing: Science Press; 2007. p. 205-6.

103. Fuehrer $H$, Igel $P$, Auer $H$. Capillaria hepatica in man-an overview of hepatic capillariosis and spurious infections. Parasitol Res. 2011;109:969-79.

104. Wang JX, Su CH, Huang JW, Cai W. Investigation on natural infection of Capillaria hepatica in rats in Xiamen. Strait J Pre Med. 2014;20:15 (in Chinese).

105. Bai GJ, Liu ZM. Clornochiasis in Jilin province. J Norman Bethune Univ Med Sci. 1984;26:672-5 (in Chinese).

106. Meerburg BG, Singleton GR, Kijlstra A. Rodent-borne diseases and their risks for public health. Crit Rev Microbiol. 2009;35:221-70.

107. Levine JM, D'Antonio CM. Forecasting biological invasions with increasing international trade. Conserv Biol. 2003;17:322-6.

108. Xu HG, Qiang S, Han ZM, Guo JY, Huang ZG, Sun HY. The distribution and introduction pathway of alien invasive species in China. Biodivers Sci. 2004; 12:626-38 (in Chinese).

109. Wang R, Wan F, Li B. Roles of Chinese Government on Prevention and Management of Invasive Alien Species. In: Wan FH, Jiang MX, Zhan AB. Biological Invasions and its Management in China. Berlin: Springer Netherlands; 2017. p. 149-156.

110. Yang $Z X$, Cheng $X$. On the legal response to the invasion of alien wild animals of China--reflection on the theory of adjustment of environmental law. J Jishou Univ. 2016:37:9-22 (in Chinese).

111. Gomez-Bautista M, Ortega-Mora LM, Tabares E, Lopez-Rodas V, Costas E. Detection of infectious Cryptosporidium parvum oocysts in mussels (Mytilus galloprovincialis) and cockles (Cerastoderma edule). Appl Environ Microb. 2000;66:1866-70.

112. Gomez-Couso H, Mendez-Hermida F, Castro-Hermida JA, Ares-Mazas E. Occurrence of Giardia cysts in mussels (Mytilus galloprovincialis) destined for human consumption. J Food Protect. 2005;68:1702-5.

113. Arkush KD, Miller MA, Leutenegger CM, Gardner IA, Packham AE, Heckeroth AR, et al. Molecular and bioassay-based detection of Toxoplasma gondii oocyst uptake by mussels (Mytilus galloprovincialis). Int J Parasitol. 2003;33:1087-97.

114. Mosteo R, Go NIP, Miguel N, Abad I, As J, Valero P, Ormad MP. Bioaccumulation of pathogenic bacteria and amoeba by zebra mussels and their presence in watercourses. Environ Sci Pollut R. 2016;23:1833-40.

115. Graczyk TK, Marcogliese DJ, de Lafontaine Y, Da Silva AJ, MhangamiRuwende B, Pieniazek NJ. Cryptosporidium parvum oocysts in zebra mussels (Dreissena polymorpha): evidence from the St. Lawrence River. Parasitol Res. 2001:87:231-4.

116. Graczyk TK, Conn DB, Lucy F, Minchin D, Tamang L, Moura LN, et al. Human waterborne parasites in zebra mussels (Dreissena polymorpha) from the Shannon River drainage area, Ireland. Parasitol Res. 2004;93:385-91.

117. Lima MG, Tunholi-Alves VICM, Bonfim TCS, Gaud E, Ncio FICN, Garcia JS, Maldonado A Jr, et al. Effects of experimental Angiostrongylus cantonensis infection on the reproductive biology of Biomphalaria straminea and Biomphalaria tenagophila. J Invertebr Pathol. 2017;149:106-13.

118. Haile T, Mariam AT, Kiros S, Teffera Z. Cockroaches as carriers of human gastrointestinal parasites in Wolkite Town, southwestern Ethiopia. J Parasitol Vector Biol. 2018;10:33-8.

119. Amaechi AA, Ogoamaka AO, Ukaga CN, Uhuegbu C, Nwachukwu MO. The epidemiological implications of cockroaches (Periplaneta americana) in the dissemination of human diseases in Owerri, south-east, Nigeria. Niger J Parasitol. 2015;36:126-31. 
120. Ukpong Gl. Prevalence of cockroaches (Periplanata americana) in households in Calabar: public health implications. J Public Health Epidemiol. 2013;5:149-52.

121. Smith DD, Frenkel JK. Cockroaches as vectors of Sarcocystis muris and of other coccidia in the laboratory. J Parasitol. 1978;64:315-9.

122. Bala AY, Sule H. Vectorial potential of cockroaches in transmitting parasites of medical importance in Arkilla, Sokoto, Nigeria. Niger J Basic Appl Sci. 2012;20:111-5.

123. Zhong D, Wang M, Pai A, Yan G. Transcription profiling of immune genes during parasite infection in susceptible and resistant strains of the flour beetles (Tribolium castaneum). Exp Parasitol. 2013;134:61-7.

124. Feary J, Cannon J, Tarzi M, Wincell S, Welch J, Cullinan P. Occupational asthma from a horticultural nematode, Steinernema feltiae. Lancet Respir Med. 2015;3:e28-9.

125. Kramarz PE, Mordarska A, Mroczka M. Response of Tribolium castaneum to elevated copper concentrations is influenced by history of metal exposure sex-specific defences, and infection by the parasite Steinernema feltiae. Ecotoxicology. 2014;23:757-66.

126. Navaneethan T, Strauch O, Ehlers RU. The influence of humidity on the effect of Steinernema feltiae against diapausing codling moth larvae (Cydia pomonella L.)(Lepidoptera: Tortricidae). Commun Agric Appl Biol Sci. 2010; 75:265-71.

127. Sohn W, Eom KS, Min D, Rim H, Hoang E, Yang Y, et al. Fishborne trematode metacercariae in freshwater fish from Guangxi Zhuang autonomous region. China Korean J Parasitol. 2009:47:249-57.

128. Torres P, Lopez JC, Cubillos V, Lobos C, Silva R. Visceral diphyllobothriosis in a cultured rainbow trout, Oncorhynchus mykiss (Walbaum), in Chile. J Fish Dis. 2002;25:375-9.

129. Dick TA, Nelson PA, Choudhury A. Diphyllobothriasis: update on human cases, foci, patterns and sources of human infections and future considerations. Southeast Asian J Trop Med Public Health. 2001;32(Suppl 2): 59-76.

130. Ryan U. Cryptosporidium in birds, fish and amphibians. Exp Parasitol. 2010; 124:113-20.

131. Revenga JE. Diphyllobothrium dendriticum and Diphyllobothrium latum in fishes from southern Argentina: association, abundance, distribution pathological effects, and risk of human infection. J Parasitol. 1993;79:379-83.

132. Han E, Shin E, Phommakorn S, Sengvilaykham B, Kim J, Rim H, et al. Centrocestus formosanus (Digenea: Heterophyidae) encysted in the freshwater fish, Puntius brevis, from Lao PDR. Korean J Parasitol. 2008; 46:49-53.

133. Umadevi K, Madhavi R. The life cycle of Haplorchis pumilio (Trematoda : Heterophyidae) from the Indian region. J Helminthol. 2006;80:327-32.

134. Scholz T, Kuchta R. Fish-borne, zoonotic cestodes (Diphyllobothrium and relatives) in cold climates: a never-ending story of neglected and (re)emergent parasites. Food Waterborne Parasitol. 2016;4:23-38.

135. Bjelić-Čabrilo O, Novakov N, Ćirković M, Kostić D, Popović E, Aleksić N, et al. The first determination of Eustrongylides excisus Jägerskiöld, 1909 — larvae (Nematoda: Dioctophymatidae) in the pike-perch Sander lucioperca in Vojvodina (Serbia). Helminthologia. 2013;50:291-4.

136. Mazandarani M, Imanpour MR, Omidzaheir S, NIAZI E. Zoonotic helminthic parasites in abdominal cavity of pike-perch, Sander lucioperca, from southeastern part of the Caspian Sea. Int J Mol Clin Microbiol. 2014;2:440-5.

137. Hernández-Gómez RE, Martínez-Salazar EA, López-Jiménez S, LeónRègagnon $\mathrm{V}$. Molecular identification of the advanced third-stage larvae (ADV L3) of Gnathostoma lamothei in Tabasco, Mexico. Parasitol Int. 2010;59:97-9.

138. León-Règagnon V, Osorio-Sarabia D, García-Prieto L, Lamothe-Argumedo R, Bertoni-Ruiz F, Oceguera-Figueroa A. New host records of the nematode Gnathostoma sp. in Mexico. Parasitol Int. 2005;54:51-3.

139. Ammar M, Arafa Ml. Cryptosporidium and other zoonotic parasites in Oreochromis niloticus in Assiut governorate. Assiut Vet Med J. 2013;55: 142-51.

140. Pinto HA, Mati VLT, Melo AL. Metacercarial infection of wild Nile tilapia (Oreochromis niloticus) from Brazil. ScientificWorldJournal. 2014;2014:807492.

141. Petersen K, O'Connell RJ, Sandige HL, Barnes SL, Danaher PJ, El Masry NA, et al. A pregnant woman with severe diarrhea. Clin Infect Dis. 2009;49:1742$1767-8$

142. Iyabo UB, ljeoma JL. Prevalence of helminth parasites of Tilapia zilli in Ebonyi River, southeastern Nigeria: implication for health management and policy. J Biosci. 2017;5:47-51.
143. Petney TN, Andrews RH, Saijuntha W, Wenz-Muecke A, Sithithaworn P. The zoonotic, fish-borne liver flukes Clonorchis sinensis, Opisthorchis felineus and Opisthorchis viverrini. Int J Parasitol. 2013;12-13:1031-46.

144. Lima Dos Santos CAM, Howgate P. Fishborne zoonotic parasites and aquaculture: A review. Aquac. 2011;3-4:253-61.

145. Phan VT, Ersboll AK, Nguyen KV, Madsen H, Dalsgaard A. Farm-level risk factors for fish-borne zoonotic trematode infection in integrated small-scale fish farms in northern Vietnam. PLoS Negl Trop Dis. 2010;7:e742.

146. Rusnak JM, Lucey DR. Clinical gnathostomiasis: case report and review of the English-language literature. Clin Infect Dis. 1993;16:33-50.

147. World Health Organization. Food safety issues associated with products from aquaculture: report of a Joint FA. 1999.

148. Thuy DT, Kania P, Buchmann K. Infection status of zoonotic trematode metacercariae in Sutchi catfish (Pangasianodon hypophthalmus) in Vietnam: associations with season, management and host age. Aquaculture. 2010;302:19-25.

149. Ljubojevi CD, Bjeli CVC, Abrilo O, Novakov N, Cirkovic M, Davidov I, Jovanovi CM, et al. Eustrongylides sp. in freshwater fish species as a potential hazard for humans. Novi Sad: Faculty of Agriculture; 2012.

150. Thu ND, Dalsgaard A, Loan LTT, Murrell KD. Survey for zoonotic liver and intestinal trematode metacercariae in cultured and wild fish in an Giang Province, Vietnam. Korean J Parasitol. 2007:45:45-54.

151. Xuan LT, Hoa P, Dekumyoy P, Hoan NH, Khuong LH. Gnathostoma infection in South Vietnam. Southeast Asian J Trop Med Public Health. 2004;35(Suppl 1):97-9.

152. Marcus S, Maqbool A, Khan N, lqbal KJ, Ashraf K, Ahmad N, et al. Food borne parasitic zoonosis with special reference to metacercarial infection in fishes. J Anim Plant Sci. 2012;22:619-21.

153. Zhang R, Gao S, Geng Y, Huang D, Yu L, Zhang S, et al. Epidemiological study on Clonorchis sinensis infection in Shenzhen area of Zhujiang delta in China. Parasitol Res. 2007;101:179-83.

154. Tesana S, Thabsripair P, Suwannatrai A, Haruay S, Piratae S, Khampoosa P, et al. Parasite surveys and environmental management for prevention of parasitic infection in cultivated Barbonymus gonionotus (Cyprinidae) in fishponds, in an opisthorchiasis endemic area of northeast Thailand. Aquaculture. 2014;428-429:54-60.

155. Kim W, Dalsgaard A, Blair D, Thanh HL. Haplorchis pumilio and H. taichui in Vietnam discriminated using ITS-2 DNA sequence data from adults and larvae. Exp Parasitol. 2009;123:146-51.

156. Thanh THD, Tuan VB, Abatih EN, Gabriel S, Thanh TGN, Quang HH, et al. Opisthorchis viverrini infections and associated risk factors in a lowland area of Binh Dinh Province, Central Vietnam. Acta Trop. 2016;157:151-7.

157. Sattari M, Mokhayer B, Khara H, Roohi JD, Nezami S. Parasitic worms of some bony fish species from the southern shore of the Caspian Sea. Bull Eur Assoc Fish Pathol. 2008;28:16-21.

158. Morgan UM, Xiao L, Limor J, Gelis S, Raidal SR, Fayer R, et al. Cryptosporidium meleagridisin an Indian ring-necked parrot (Psittacu la krameri). Aust Vet J. 2000;78:182-3.

159. Graczyk TK, Fayer R, Trout JM, Lewis EJ, Farley CA, Sulaiman I, et al. Giardia sp. cysts and infectious Cryptosporidium parvum oocysts in the feces of migratory Canada geese (Branta canadensis). Appl Environ Microbiol. 1998; 64:2736-8.

160. Dieter JR, Dieter RS, Gulliver G. Zoonotic diseases: health aspects of Canadian geese. Int J Circumpolar Health. 2001;60:676-84.

161. Dubey JP, Parnell PG, Sreekumar C, Vianna MCB, De Young RW, Dahl E, et al. Biologic and molecular characteristics of Toxoplasma gondii isolates from striped skunk (Mephitis mephitis), Canada goose (Branta canadensis), blackwinged lory (Eos cyanogenia), and cats (Felis catus). J Parasitol. 2004;90:1171-4.

162. Graczyk TK, Majewska AC, Schwab KJ. The role of birds in dissemination of human waterborne enteropathogens. Trends Parasitol. 2008;24:55-9.

163. Horák P, Kolářová L. Snails, waterfowl and cercarial dermatitis. Freshw Biol. 2011:56:779-90.

164. Deng Z, Zhang Q, Huang S, Jones JL. First provincial survey of Angiostrongylus cantonensis in Guangdong Province, China. Trop Med Int Health. 2012;17:119-22.

165. Zhang R, Chen M, Gao S, Geng Y, Huang D, Liu J, et al. Enzootic Angiostrongyliasis in Shenzhen, China. Emerg Infect Dis. 2008;14:1955-6.

166. Hu QA, Zhang Y, Guo YH, Lv S, Xia S, Liu HX, Fang Y, Liu Q, Zhu D, Zhang QM, Yang CL, Lin GY. Small-scale spatial analysis of intermediate and definitive hosts of Angiostrongylus cantonensis. Infect Dis Poverty. 2018;7(1):100.

167. Chikweto A, Bhaiyat MI, Macpherson CNL, DeAllie C, Pinckney RD, Richards $C$, et al. Existence of Angiostrongylus cantonensis in rats (Rattus norvegicus) in Grenada, West Indies. Vet Parasitol. 2009;162:160-2. 
168. Munehiro O, Osamu F, Jiro A, Tsutomu K, Yuzaburo O, Masao K. Natural Echinococcus multilocularis infection in a Norway rat, Rattus norvegicus, in southern Hokkaido, Japan. Int J Parasitol. 1992;22:681-4.

169. Seong JK, Huh S, Lee J, Oh Y. Helminths in Rattus norvegicus captured in Chunchon, Korea. Korean J Parasitol. 1995;33:235-7.

170. Waugh CA, Lindo JF, Foronda P, MIA A-S, Lorenzo-Morales J, Robinson RD. Population distribution and zoonotic potential of gastrointestinal helminths of wild rats Rattus rattus and R. norvegicus from Jamaica. J Parasitol. 2006;92:1014-8.

171. Hancke D, Navone GT, Suarez OV. Endoparasite community of Rattus norvegicus captured in a shantytown of Buenos Aires City, Argentina. Helminthologia. 2011;48:167-73.

172. Webster JP, MacDonald DW. Cryptosporidiosis reservoir in wild brown rats (Rattus norvegicus) in the UK. Epidemiol Infect. 1995;115:207-9.

173. Rafique A, Rana SA, Khan HA, Sohail A. Prevalence of some helminths in rodents captured from different city structures including poultry farms and human population of Faisalabad, Pakistan. Pak Vet J. 2009;29:141-4.

174. Motazedian MH, Parhizkari M, Mehrabani D, Hatam G, Asgari Q. First detection of Leishmania major in Rattus norvegicus from Fars Province, Southern Iran. Vector Borne Zoonotic Dis. 2010;10:969-75.

175. Papadogiannakis E, Spanakos G, Kontos V, Menounos PG, Tegos N, Vakalis N. Molecular detection of Leishmania infantum in wild rodents (Rattus norvegicus) in Greece. Zoonoses Public Health. 2010;57:E23-5.

176. Pozio E. The broad spectrum of Trichinella hosts: from cold- to warmblooded animals. Vet Parasitol. 2005;132:3-11.

177. Macpherson CN. The epidemiology and public health importance of toxocariasis: a zoonosis of global importance. Int J Parasitol. 2013;43:999-1008.

178. Garedaghi Y, Khaki AA. Prevalence of gastrointestinal and blood parasites of rodents in Tabriz, Iran, with emphasis on parasitic zoonoses. Crescent J Med Biol Sci. 2014;1:9-12.

179. Kataranovski D, Kataranovski M, Deljanin I. Helminth fauna of Rattus norvegicus Berkenhout, 1769 from the Belgrade area, Serbia. Arch Biol Sci. 2010;62:1091-100.

180. Tappe D, Abdullah S, Heo CC, Kutty KM, Latif B. Human and animal invasive muscular sarcocystosis in Malaysia - recent cases, review and hypotheses. Trop Biomed. 2013;30:355-66.

181. Singleton GR, Joshi RC, Sebastian LS. Philippine rats: ecology and management; 2008.

182. He YX, Salafsky B, Ramaswamy K. Host-parasite relationships of relationships Schistosoma japonicum in mammalian hosts. Trends Parasitol. 2001;17:320-4.

183. Fayer R. Cryptosporidium: a water-borne zoonotic parasite. Vet Parasitol. 2004;126:37-56

184. Mas-Coma MS, Esteban JG, Bargues MD. Epidemiology of human fascioliasis: a review and proposed new classification. Bull World Health Organ. 1999;77: 340-6.

185. Mafiana CF, Osho MB, Sam-Wobo S. Gastrointestinal helminth parasites of the black rat (Rattus rattus) in Abeokuta, Southwest Nigeria. J Helminthol. 1997:71:217-20.

186. Ashford RW. The leishmaniases as emerging and reemerging zoonoses. Int Parasitol. 2000;30:1269-81.

187. Cabanacan-Salibay C, Claveria FG. Toxoplasma gondii infection in Philippines Rattus spp. confirmed through bioassay in Mus musculus. Vet Arh. 2006:4:351-61.

188. Morgan JA, Dejong RJ, Adeoye GO, Ansa E, Barbosa CS, Br E, Mond P, et al. Origin and diversification of the human parasite Schistosoma mansoni. Mol Ecol. 2005;14:3889-902.

189. Ogunniyi T, Balogun H, Shasanya B. Ectoparasites and endoparasites of peridomestic house-rats in Ile-lfe, Nigeria and implication on human health. Iran J Parasitol. 2014:9:134-40.

190. Sak B, Kváč M, Květoňová D, Albrecht T, Piálek J. The first report on natural Enterocytozoon bieneusi and Encephalitozoon spp. infections in wild eastEuropean house mice (Mus musculus musculus) and west-European house mice (M. m. domesticus) in a hybrid zone across the Czech Republic-Germany border. Vet Parasitol. 2011;178:246-50.

191. Resendes AR, Amaral AFS, Rodrigues A, Almeria S. Prevalence of Calodium hepaticum (Syn. Capillaria hepatica) in house mice (Mus musculus) in the Azores archipelago. Vet Parasitol. 2009;160:340-3

192. Sharma D, Joshi S, Vatsya S, Yadav CL. Prevalence of gastrointestinal helminth infections in rodents of Tarai region of Uttarakhand. J Parasit Dis. 2013:37:181-4.

193. Allymehr M, Tavassoli M, Manoochehri MH, Ardavan D. Ectoparasites and gastrointestinal helminths of house mice (Mus musculus) from poultry houses in Northwest Iran. Comp Parasitol. 2012;79:283-7.
194. Parhizkari M, Motazedian MH, Asqari Q, Mehrabani D. The PCR-based detection of Leishmania major in Mus musculus and other rodents caught in southern Iran: a guide to sample selection. Ann Trop Med Parasitol. 2011; 105:319-23.

195. Chen D, Zhang Y, Shen H, Wei Y, Huang D, Tan Q, et al. Epidemiological survey of Angiostrongylus cantonensis in the west-central region of Guangdong Province, China. Parasitol Res. 2011;109:305-14.

196. Sukontason K, Sukontason KL, Boonsriwong N, Chaithong U, Piangjai S, Choochote W. Development of Haplorchis taichui (Trematoda: Heterophyidae) in Mus musculus mice. Southeast Asian J Trop Med Public Health. 2001;32(Suppl 2):43-7.

197. Kijlstra A, Eissen OA, Cornelissen J, Munniksma K, Eijck I, Kortbeek T. Toxoplasma gondii infection in animal-friendly pig production systems. Invest Ophthalmol Vis Sci. 2004;45:3165-9.

198. Corrêa FM, Chieffi PP, Lescano SA, Santos SV. Behavioral and memory changes in Mus musculus coinfected by Toxocara canis and Toxoplasma gondii. Rev Inst Med Trop Sao Paulo. 2014:56:353-6.

199. Smyth JD, Smyth MM. Natural and experimental hosts of Echinococcus Granulosus and E. Multilocularis, with comments on the genetics of speciation in the genus Echinococcus. Parasitology. 1964;54:493-514.

200. Antinori S, Galimberti L, Milazzo L, Corbellino M. Plasmodium knowlesi: the emerging zoonotic malaria parasite. Acta Trop. 2013;125:191-201.

201. Chaisiri K, Chaeychomsri W, Siruntawineti J, Bordes F, Herbreteau V, Morand S. Human-dominated habitats and helminth parasitism in southeast Asian murids. Parasitol Res. 2010;107:931-7.

202. Blasdell K, Bordes F, Chaisiri K, Chaval Y, Claude J, Cosson J, et al. Progress on research on rodents and rodent-borne zoonoses in south-East Asia. Wild Res. 2015:42:98-107.

203. Fuehrer $\mathrm{H}$. An overview of the host spectrumand distribution of Calodium hepaticum (syn. Capillaria hepatica): part 1-Muroidea. Parasitol Res. 2014;113: 619-40.

204. Chaisiri K, Siribat P, Ribas A, Morand S. Potentially zoonotic helminthiases of murid rodents from the indo-Chinese peninsula: impact of habitat and the risk of human infection. Vector Borne Zoonotic Dis. 2015;15:73-85.

205. Jittapalapong S, Sarataphan N, Maruyama S, Hugot J, Morand S, Herbreteau V. Toxoplasmosis in rodents: ecological survey and first evidences in Thailand. Vector Borne Zoonotic Dis. 2011;11:231-7.

206. Romig T, Dinkel A, Mackenstedt U. The present situation of echinococcosis in Europe. Parasitol Int. 2006;55(Suppl):S187-91.

207. Mathy A, Hanosset R, Adant S, Losson B. The carriage of larval Echinococcus multilocularis and other cestodes by the musk rat (Ondatra zibethicus) along the ourthe river and its tributaries (Belgium). J Wildl Dis. 2009;45:279-87.

208. Borucinska JD, Nielsen SW. Hepatic capillariasis in muskrats (Ondatra zibethicus). J Wildl Dis. 1993;29:518-20.

209. Nardoni S, Angelici MC, Mugnaini L, Mancianti F. Prevalence of Toxoplasma gondii infection in Myocastor coypus in a protected Italian wetland. Parasit Vectors. 2011:4:240.

210. Gayo V, Cuervo P, Rosadilla D, Birriel S, Dell'Oca LIA, Trelles A, et al. Natura Fasciola hepatica infection in nutria (Myocastor coypus) in Uruguay. J Zoo Wildlife Med. 2011;42:354-6.

211. Rossin MIAA, Varela G, Timi JT. Strongyloides myopotami in ctenomyid rodents: transition from semi-aquatic to subterranean life cycle. Acta Parasitol. 2009:54:257-62

212. Park J, Novilla MN, Song J, Kim K, Chang S, Han J, et al. The first case of Capillaria hepatica infection in a nutria (Myocastor coypus) in Korea. Korean J Parasitol. 2014;52:527.

213. Halov AD, Mulcahy G, Rafter P, Tur VC, Ekov AL, Grant T, De Waal T. Toxoplasma gondii in Ireland: seroprevalence and novel molecular detection method in sheep, pigs, deer and chickens. Zoonoses Public Health. 2013;60:168-73.

214. Dozi E, Res A, Pisanu B, Gerriet O, Lapeyre C, Stuyck J, Chapuis J. Macroparasites of Pallas's squirrels (Callosciurus erythraeus) introduced into Europe. Vet Parasitol. 2010:172:172-6.

215. Tuan Y, Kuo H, Yin J, Chang F, Tung K, Chang W, et al. Case report: angiostrongyliasis in a pallas'squirrel (Callosciurus Erythraeus). Taiwan Vet J. 2018:44:1-5

216. Lv C, Zhang L, Wang R, Jian F, Zhang S, Ning C, et al. Cryptosporidium spp. in wild, laboratory, and pet rodents in China: prevalence and molecular characterization. Appl Environ Microbiol. 2009;75:7692-9.

217. Ng OT, Ooi EE, Lee CC, Lee PJ, Ng LC, Pei SW, et al. Naturally acquired human Plasmodium knowlesi infection, Singapore. Emerg Infect Dis. 2008;14: 814-6. 
218. Rivera WL, Yason JAD, Adao DEV. Entamoeba histolytica and E. dispar infections in captive macaques (Macaca fascicularis) in the Philippines. Primates. 2010;51:69-74.

219. Zanzani SA, Gazzonis AL, Epis S, Manfredi MT. Study of the gastrointestinal parasitic fauna of captive non-human primates (Macaca fascicularis). Parasitol Res. 2016;115:307-12.

220. Kan SP, Pathmanathan R. Review of sarcocystosis in Malaysia. Southeast Asian J Trop Med Public Health. 1991;22(Suppl):129-34.

221. Li M, Zhao B, Li B, Wang Q, Niu L, Deng J, et al. Prevalence of gastrointestinal parasites in captive non-human primates of twenty-four zoological gardens in China. J Med Primatol. 2015;44:168-73.

222. Renquist DM, Whitney RA Jr. Zoonoses acquired from pet primates. Vet Clin North Am Small Anim Pract. 1987;17:219-40.

223. Matz-Rensing K, Lampe K, Rohde G, Roos C, Kaup F. Massive visceral Pentastomiasis in a long-tailed macaque--an incidental finding. J Med Primatol. 2012;41:210-3.

224. Sricharern W, Inpankaew T, Keawmongkol S, Supanam J, Stich RW Jittapalapong S. Molecular detection and prevalence of Giardia duodenalis and Cryptosporidium spp. among long-tailed macaques (Macaca fascicularis) in Thailand. Infect Genet Evol. 2016;40:310-4.

225. Melfi V, Poyser F. Trichuris burdens in zoo-housed Colobus guereza. Int J Primatol. 2007:28:1449-56.

226. Tappe D, Brehm K, Frosch M, Blankenburg A, Schrod A, Kaup F, et al. Echinococcus multilocularis infection of several Old World monkey species in a breeding enclosure. Am J Trop Med Hyg. 2007;77:504-6.

Ready to submit your research? Choose BMC and benefit from:

- fast, convenient online submission

- thorough peer review by experienced researchers in your field

- rapid publication on acceptance

- support for research data, including large and complex data types

- gold Open Access which fosters wider collaboration and increased citations

- maximum visibility for your research: over $100 \mathrm{M}$ website views per year

At $\mathrm{BMC}$, research is always in progress.

Learn more biomedcentral.com/submissions 